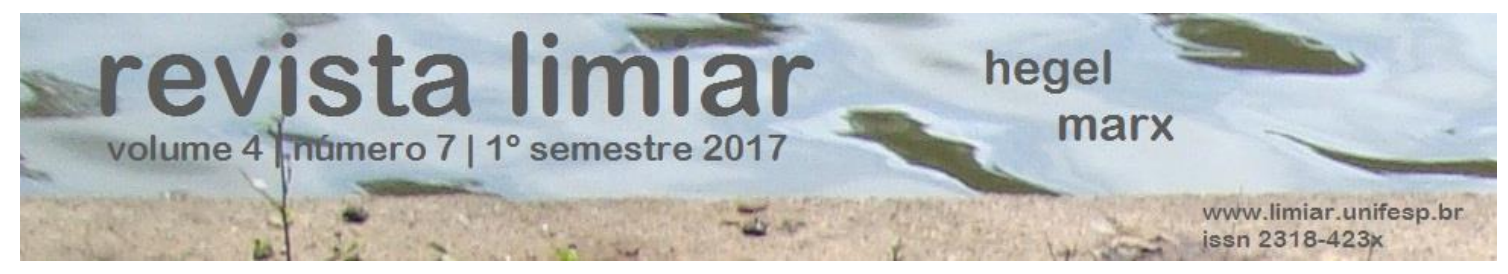

\title{
Jean-Claude Bourdin1
}

\section{O ATEÍSMO DE HOLBACH À LUZ DE HEGEL ${ }^{2}$}

Tradução: Fábio Rodrigues de Ávila ${ }^{3}$

Resumo: Apesar da importância central do ateísmo no sistema materialista de Holbach, é evidente que a leitura de Hegel do pensamento de Holbach em suas Lições sobre a Filosofia da História, apesar de original, não o menciona. As razões para este silêncio podem ser facilmente deduzidas do que ele considerava serem as tarefas da filosofia em relação à religião, ou seja, para garantir sua reconciliação, que é aperfeiçoada conceitualmente pois ela torna real o itinerário do mundo espiritual cristão. O ateísmo poderia surgir apenas como uma filosofia irrelevante, o que explica porque Hegel nem mesmo se importou em refutá-lo. Entretanto, nós podemos mostrar que, em sua crítica à doutrina do "conhecimento imediato" e do sentimentalismo religioso, Hegel fornece um meio de justificar filosoficamente o ateísmo do barão, apresentando-o como o "resultado" do sentimentalismo e a conseqüência de um pensamento religioso que esvazia seu conteúdo.

Palavras-chave: ateísmo, materialismo, Hegel, Holbach, religião.

Abstract: D'Holbachs atheism as seen by Hegel. Despite the central importance of atheism in d'Holbach's materialistic system, it is clear that Hegel's reading of d'Holbach's thought in his Lessons on the Philosophy of History, although original, does not mention it. The reasons for this silence can be easily deduced from what he considered to be the tasks of philosophy in relation to religion, namely to ensure their reconciliation which is conceptually mastered as it realizes the programme of the Christian spiritual world. Atheism could only appear as an irrelevant philosophy, which is why Hegel did not even bother to refute it. Nevertheless we can show that in his criticism of the doctrine of "immediate knowledge" and of religious sentimentalism, Hegel provides a way of justifying philosophically the Baron's atheism by presenting it as the "result" of sentimentalism and the consequence of a religious thought that finitizes its content.

Keywords: atheism, materalism, Hegel, Holbach, religion.

\footnotetext{
1 Professor emérito do Departamento de Filosofia da Université de Poitiers, França.

2 Artigo originalmente publicado em Revue Dix-huitième Siècle, no-24, 1992, pp. 213-226.

3 Doutorando em Filosofia na Universidade Federal de São Paulo, integrante do Scripta - Laboratório de Leitura, Tradução e Escrita (Departamento de Filosofia, EFLCH-UNIFESP).
} 
Se a historiografia tradicional das Luzes tende a minimizar o ateísmo dos philosophes, é antes de tudo incompreensível que ocorra mais ou menos o mesmo, quando se trata dos materialistas franceses, inclusive nos comentadores que buscaram realçar o interesse e a originalidade desta filosofia. Dentre suas teses "ultrapassadas", seria preciso contar o ateísmo, que, por isso mesmo, não teria um valor maior do que uma mera curiosidade?

Nós nos propomos a partir de uma constatação idêntica à que parece sugerir a leitura oferecida por Hegel sobre a filosofia materialista francesa do século XVIII. Mas por que então tomar Hegel como testemunha? Primeiramente porque ele é o último grande filósofo a ter elaborado uma história filosófica da filosofia e, nela, não se esquivou da questão do materialismo francês. Em seguida, e paradoxalmente, por conta do interesse que apresenta a distância especulativa que separa Hegel do materialismo, o que o torna mais livre a seu respeito, se comparado àqueles que, na França do século XIX, propuseram-se a refutá-lo. Depois, porque se pode mostrar que ele soube propor, algumas vezes, não sem certa dificuldade, uma interpretação correta a respeito da originalidade de alguns dos temas desta filosofia. ${ }^{4}$ Em particular, são as teses materialistas cruciais de Holbach, que são interrogadas e interpretadas, embora seletivamente. Enfim, o ateísmo nos parece um bom teste da leitura hegeliana (poderia ela compreendê-lo?); em contrapartida, ela poderia apresentar o ateísmo sob nova luz.

À primeira vista, a análise hegeliana parece decepcionante. Com efeito, a seção das Lições sobre a história da filosofia, consagrada à filosofia francesa, não concede senão um lugar restrito ao ateísmo das Luzes. Se o tema é seguramente evocado, ele está sempre associado ao materialismo, embora ele não seja nem estudado, nem interpretado, nem sequer refutado por Hegel. Curiosamente: o parágrafo que trata do pensamento de Holbach não faz sequer alusão a ele. Ora, é manifesto que, para o autor do Sistema da Natureza, o ateísmo não está apenas implicado em seu materialismo, pelo contrário, ele é abertamente reivindicado como sendo seu objetivo essencial. No Sistema da Natureza, nos trinta capítulos que o livro contém, quatorze são explicitamente consagrados à crítica dos dogmas teológicos e à defesa e ilustração do ateísmo. A abordagem polêmica do barão não se limita ao conteúdo da teologia e da metafisica; ela ataca igualmente as posições deístas, céticas, os falsos ateus, para apresentar o ateísmo como a única doutrina capaz de fundar uma política e uma moral da virtude e da felicidade. Le Bon sens é uma obra

\footnotetext{
${ }^{4}$ É necessário destacar o caso de La Mettrie que é simplesmente "sacrificado" por Hegel. Sobre este ponto, assim como a interpretação dos materialistas franceses por Hegel, eu me permito remeter a meu livro Hegel et les materialistes français du 18e siècle (Paris, Méridiens Klincksieck, 1992).
} 
inteiramente organizada em torno da destruição da religião e do cristianismo, em particular. Considerada como uma versão vulgarizada do Sistema da Natureza, esta obra revela claramente quais eram as intenções do barão. As teses empiristas e materialistas contidas ali não intervêm senão incidentemente para escorar os argumentos ateus que são desenvolvidos mais substancialmente, como se Holbach estivesse apressado em chegar a eles. Assim, após ter dito que a definição de Deus como Espírito é ininteligível, ele indica, de passagem:

Não é mais natural e mais inteligível tirar tudo o que existe do seio da matéria, cuja existência é demonstrada por nossos sentidos, dos quais experimentamos os efeitos a cada instante [...], do que atribuir a formação das coisas a uma força desconhecida, a um ser espiritual que não pode tirar de sua base senão aquilo que ele próprio contém, e que, pela essência espiritual que a ele se atribui, é incapaz de fazer ou de colocar em movimento o que quer que seja? ${ }^{5}$

Ou ainda, três capítulos ${ }^{6}$ são suficientes para estabelecer que a matéria se move por si mesma, conforme ao princípio que admite que "o movimento é a essência da matéria", 7 para criticar a ideia de criação divina do mundo ou o recurso às causas sobrenaturais. Enfim, são necessários apenas dois capítulos para expor a teoria gnosiológica do barão: trata-se também de fazer admitir que a ideia de Deus é ininteligível e não poderia ser admitida senão em detrimento das regras da evidência racional mais imediata:

A evidência não pode se fundar, para os homens, senão no testemunho constante de nossos sentidos, que sozinhos fazem nascer ideias e nos inclinam a julgar sua conveniência ou sua incompatibilidade. $O$ que existe necessariamente é aquilo cuja não-existência implicaria contradição. Estes princípios, reconhecidos por todo mundo, estão em falta sempre que se trata da existência de Deus. ${ }^{8}$

Assim, posto de lado o Christianisme dévoilé e outros textos e panfletos antirreligiosos do barão, cujo propósito é evidente (La Contagion Sacrée, Teologia Portátil, Histoire critique de Jésus-Christ etc.), parece ainda que o Sistema da Natureza e Le Bon sens são animados pela intenção de estabelecer a possibilidade, a necessidade e a excelência prática do ateísmo: o materialismo holbachiano poderia ser definido como a via mais natural (em todos os sentidos do termo) para orientar-se

\footnotetext{
5 D'HOLBACH, Le Bon Sens, Les Éditions rationalistes, 1971, p.18.

6 Id., ibid. p.28-29.

7 ld., ibid. p.29.

${ }^{8}$ Id., ibid. p. 16.
} 
no rumo de uma "apatia feliz" ${ }^{9}$ e do ateísmo, os únicos resultados verdadeiros do materialismo, que os prepara e os justifica.

Ora, de tal empreendimento, apesar de evidente para quem lê a totalidade do Sistema da Natureza, Hegel, que o leu, dele não retém nada em suas Lições.

Mais exatamente, parece não querer distinguir o materialismo do ateísmo e, falando do primeiro, contenta-se de nele englobar o segundo, tanto que isso aparece no curso de 1825-1826:

No presente caso, é precisamente por conta do ateísmo que tal filosofia é triunfante: ela determinou o último, o ativo, o eficiente como matéria, natureza, etc. Pode-se dizer que isso, em suma, é espinosismo, que põe em seu começo, a título de princípio último, a unidade da substância. ${ }^{10}$

O ateísmo é a consequência do materialismo: se "o último" é a matéria, o monismo materialista (seu "espinosismo", em suma) impede que seja reservada a possibilidade de uma substância imaterial. Mas, por outro lado, e diferentemente de Espinosa, por conta dos pressupostos empiristas que fundam o conceito dessa matéria, nenhuma ideia de infinito pode vir a mediar os modos finitos nos quais esta substância se realiza. O materialismo é, grosso modo, o ateísmo do mundo físico e do mundo moral.

De outro modo, quando Hegel alude à luta antirreligiosa da filosofia francesa, não é o materialismo ateu que é especialmente visado, já que nessa polêmica, filósofos tão diferentes como Voltaire, La Mettrie, Helvétius, Diderot, Holbach, D'Alembert e Rousseau encontram-se sob temas frequentemente muito próximos. A mesma luta ainda é objeto de uma apreciação matizada. Tudo acontece como se, depois de ter reconhecido sua importância, Hegel quisesse, justificando-a pelo estado de imoralidade generalizada que atingira a Igreja na França, relativizar seu alcance: não é toda religião, ainda menos o cristianismo, que teriam sido atacados, mas uma forma morta e ultrapassada de religião; disso, o grau de "positividade" (isto é, de perda de sentido) alcançado pelo catolicismo no Antigo Regime foi a ilustração:

Para nós, é fácil reprovar os franceses em seus ataques contra a religião [...] Mas que religião! Não aquela que foi purificada por Lutero, mas a superstição mais vergonhosa, a velhacaria, a tolice, a depravação do espírito; e sobretudo a dissipação das riquezas. ${ }^{11}$

\footnotetext{
9 D'HOLBACH: Système de la nature, édition de 1821, réimpr. Olms 1966, p.289.

${ }_{10}^{10}$ HEGEL, F.W. : Leçons sur l'histoire de la philosophie, trad. Garniron, Vrin, VI, p.1720.

11 ld., Ibid. VI, p.1784.
} 
Entretanto, para Hegel, a desrazão e a "positividade" na história, como no pensamento, não se eliminam espontaneamente, é necessário sempre submetê-los à crítica teórica e prática e dar-lhes, também, o golpe de misericórdia. O mérito de contribuir conscientemente para a destruição das formas de "positividade" que, entretanto, "já estava destruída em si", ${ }^{12}$ não é jamais pequeno, uma vez que ele testemunha que uma nova forma do Espírito se desembaraçou e tomou consciência de si mesma na individualidade vivente de uma filosofia singular. Hegel chama de coragem, heroísmo, esta maneira que um pensador tem de assumir, na sua singularidade, a atual tarefa do Espírito, isto é, a necessidade do progresso da filosofia, que assume a postura de uma refutação daquilo que esse mesmo Espírito produzira em uma etapa anterior de seu desenvolvimento. Os franceses, e dentre eles, como o mostra a seção das Lições, os materialistas, foram os agentes dessa autocrítica histórica e especulativa do Espírito.

Pode-se dizer então que o ateísmo aparece para Hegel como uma forma ultrapassada. O elogio hegeliano funciona, como frequentemente em sua obra, enquanto afirmação de sua relatividade histórica: se era necessário que a filosofia francesa submetesse a religião e seus dogmas à crítica da intelecção (die Einsicht da Fenomenologia), para nós, esse combate não tem mais a mesma atualidade, porque seu alvo é atingido no que tem de essencial. O sucesso do ateísmo antirreligioso do século XVIII significa ao mesmo tempo sua caducidade. Os problemas que Hegel tinha para enfrentar situavam-se verdadeiramente, a seus olhos, em um outro nível de dificuldades: apesar da "reconciliação" filosófica efetuada pelas Lições sobre a filosofia da religião, restava-Ihe pensar e resolver a "dissonância" (Misston) persistente entre a religião e a filosofia, assim como entre a Comunidade espiritual e a realidade empírica. $^{13}$

Mas é sobretudo de um ponto de vista filosófico que o ateísmo devia talvez parecer algo sem grande interesse para Hegel, e não poderia entrar em ressonância com as exigências da filosofia como Especulação. Com efeito, o Saber absoluto representa a integração concebida, na filosofia, da figura mais desenvolvida da religião, a Religião manifesta, e a tradução, no elemento do conceito, do conteúdo, em si especulativo, do cristianismo, para saber que Deus é Espírito, em sua comunidade histórica. A ideia de que o cristianismo ao longo de sua história não teria sido nada mais do que uma longa aberração, fruto das paixões mais tristes e mais baixas dos homens, produto do embuste dos padres, é, de modo evidente, totalmente estranha a

\footnotetext{
12 Op.cit.

${ }^{13}$ HEGEL, F.W., Leçons sur la philosophie de la religion, trad. Gibelin, Vrin, 1971. III, p.215 e 217.
} 
Hegel e à sua filosofia do Espírito absoluto. ${ }^{14} \mathrm{O}$ cristianismo representa esse "gonzo em torno do qual cumpre-se a história universal", ${ }^{15}$ em que a vinda de Cristo significa que o Deus-Espírito torna-se manifesto para o homem e autoriza a mediação de sua finitude. O cristianismo mostra, na aparição, na missão, na paixão e na ressurreição de Cristo, o que é o Espírito em sua verdade: "Mas o que é o Espírito? É o Um, o infinito igual a si mesmo, a identidade pura que, em segundo lugar, se separa de si, como o outro si-mesmo, como a existência para si e em si em face do universal". ${ }^{16}$ Cristo é o Outro a quem o Espírito se opõe a fim de retornar a si-mesmo, desde sua diferença, em sua unidade. Mas em sua particularização, esse Outro "é o mundo, a natureza e o espírito finito; o espírito finito é então posto como momento de Deus. Assim o próprio homem é compreendido no conceito de Deus". ${ }^{17}$ Estas linhas são o bastante para mostrar tudo o que separa Hegel do ateísmo de um Holbach e do humanismo da finitude que o sustém. Se, à sua maneira, o materialismo holbachiano exprime uma necessidade de unidade teórica e de reconciliação do homem consigo mesmo, ${ }^{18}$ é a partir de um pressuposto radicalmente afastado por Hegel: é a natureza que é, de pleno direito, o elemento cuja reconciliação é eternamente efetuada por Holbach. ${ }^{19}$

Parece claro que nenhum debate tenha sido possível entre Hegel e Holbach a respeito do ateísmo, e, isso, em um ponto decisivo. Como dizem as primeiras páginas das Lições sobre a filosofia da religião, se não cabe à filosofia produzir nos homens o sentimento religioso, é porque ela deve "supor que o sujeito triunfa sobre si-mesmo a esse respeito", explica Hegel, enigmaticamente. Mas o que é preciso compreender, talvez, é que a ideia de que um homem possa ser avesso à religião é absolutamente inconcebível, porque a religião não é algo de estranho à consciência:

Todavia, não há, de fato, nenhum homem pervertido, perdido, miserável ao ponto de não ter nenhuma religião, de não a conhecer, de não ter dela nenhuma ideia, ainda que fosse para temê-la, ter dela, ao menos, desejo ou o ódio. Como o homem é um homem e não um animal, a religião não poderia ser para ele um sentimento ou uma intuição exterior. ${ }^{20}$

\footnotetext{
14 Para a crítica hegeliana da teoria do embuste sacerdotal, ver a versão de 1800 do começo de $L a$ positivité de la religion chértienne, trad. sob direção de Guy PLanty-Bonjour (PUF, 1983), e a Phénoménologie de l'Esprit, trad. Hyppolite, II, p.96 e 103.

${ }^{15}$ HEGEL, F.W., Leçons sur la philosophie de l'histoire, trad. Gibelin, Vrin, 1946, p.291.

16 Id., ibid., p.294.

17 Op.cit., p.295.

18 Ver S.N., II, p.149 e as condenações dos sistemas que fazem "o homem duplo" e separam-no da natureza.

${ }^{19}$ De onde a afirmação muitas vezes repetida, segundo a qual é preciso retornar à natureza e reencontrar o solo das certezas sensíveis.

${ }^{20}$ HEGEL, Phil.Relig., I, p.17.
} 
$\mathrm{O}$ ateu que alegasse, como o fez Holbach, que o sentimento religioso é o resultado de uma educação, logo, de uma imposição exterior à consciência e ao espírito, ${ }^{21}$ seria, aos olhos de Hegel, vítima de um equívoco tão pouco filosófico quanto seria a doutrina que quisesse conceder ao finito uma validade absoluta. De resto, seria apenas possível, de um ponto de vista hegeliano, afirmar que jamais houvera filósofos ateus? Por diversas vezes Hegel observa que o ateísmo tem sido frequentemente uma acusação, uma categoria polêmica, e que é uma nova ideia do divino e um aprofundamento de seu conceito que foram taxados de ateísmo. ${ }^{22} \mathrm{De}$ modo a compreender que as querelas doutrinais sobre este assunto são, frequentemente, o fruto de confusões conceituais e são menos importantes que o creem seus próprios atores.

Mas em relação aos materialistas franceses do século XVIII ele é, aparentemente, obrigado a convir que, "neste caso, é precisamente por conta do ateísmo que tal filosofia emergiu". ${ }^{23}$ Entretanto, e por todas as razões que evocamos, parece que ele pertence a um momento ultrapassado da história da filosofia e da cultura e que apenas uma piedade sem reflexão seja capaz, hoje, de recolocar "em circulação esta velha palavra", a do ateísmo, "já quase esquecida", ${ }^{24}$ e de assim lhe fazer as honras de uma irrisória sobrevida.

Enfim, o ateísmo parece sobretudo estranho em relação àquilo que para Hegel é a tarefa filosófica fundamental, possível apenas hoje, aquela de reconciliar especulativamente filosofia e religião.

Ora, o ateísmo não somente fracassaria nessa tarefa, como ele está, pode-se dizer, fora deste contexto. Ele é essencialmente negativo e, como a intelecção da qual Hegel fornece uma análise na Fenomenologia do Espírito, ${ }^{25}$ só se realiza na negação daquilo que ele não é: o ateísmo é uma doutrina subordinada, que não se preenche de um conteúdo, do qual ele é por princípio desprovido, exceto por ocasião de sua crítica. Em segundo lugar, a crítica do conteúdo religioso pode ser qualificada de "selvagem": ela pretende liquidar toda religião, ao passo que só critica suas formas mais "positivas", mas sem dar-se os meios de pensar aquilo que rejeita. Daí as

\footnotetext{
21 Ver, por exemplo, estas linhas: "Vê-se como os ideais de Deus produzidos na origem pela ignorância, admiração e o temor; adotados pela inexperiência e pela incredulidade; propagados pela educação, pelo exemplo, pelo hábito, pela autoridade, tornam-se invioláveis e sagrados; nós os temos recebido contra nossa vontade sob as palavras de nossos pais, nossos instrutores, nossos legisladores e nossos padres! " (S.N., II, 50-51).

${ }^{22}$ Ver Hist.Phil., VI, p.1720.

23 lbid.

${ }^{24}$ Carta a Creuzer, maio 1821, Correspondance, trad. Carrère, II, p.235 (citado em G. Lebrun, La Patience du concept, Gallimard, 1972, p.128).

25 Ver Phénoménologie de...op.cit., t. II, p.93-125.
} 
incompreensões e a má-fé assinaladas por Hegel na Fenomenologia do Espírito. ${ }^{26}$ Enfim, e diga-se de passagem, o ateísmo é impróprio para produzir no domínio do político e da eticidade, que é um dos aspectos fundamentais da questão moderna do Estado: inscrever o direito no sentimento, na convicção íntima e na disposição do espírito (a intraduzível Gesinnung) dos indivíduos: "O governo e o povo devem, um em relação ao outro, possuir essa garantia última do sentimento (Gesinnung), e não o podem fazê-lo senão através de uma religião que não se oponha à constituição racional do Estado". ${ }^{27}$

Se a filosofia hegeliana da religião se propõe a reconciliar especulativamente as duas figuras do Espírito absoluto, é porque ela considera a reconciliação como o tema que orquestrou a história das relações conflitantes entre a razão e a fé, a filosofia e a teologia, a liberdade e a autoridade. Em todo caso, é desde o cristianismo que "a filosofia dos tempos modernos é em si já unida à religião, porque ela teve sua origem no mundo cristão"; ${ }^{28}$ o Espírito, não podendo, por sua essência, tolerar as oposições que só resolveriam pela supressão ou pela dominação de um dos dois termos. É o que a história precisamente mostrou oferecendo, sucessivamente, três tipos de reconciliações igualmente faltosas e ordinárias: seja a dominação do princípio religioso (o suplício de Vanini); seja a indiferença recíproca e a paz ilusória; seja o deísmo das Luzes. O momento da Aufklärung viu a razão, sob a forma do entendimento analítico e da intelecção abstrata, conseguir que a religião e a fé renunciassem ao seu conteúdo e se tornassem "racionais", "razoáveis", "esclarecidas". O simplório deísmo das luzes limitou-se a professar alguns dogmas superficiais "como por exemplo que há um Deus, que um homem, Cristo, aparecera para ensinar os mandamentos de Deus", no entanto, a filosofia racionalista reconhece sua insipidez e sua vacuidade na sua incapacidade para reunir o significado dos mistérios e dos dogmas. ${ }^{29}$

Constata-se que o ateísmo não é evocado entre estas três reconciliações falhas e compreende-se porquê. Cada uma delas buscava algo como um compromisso (dominação, indiferentismo, aclimatação de um ao outro). Ora, está claro que o ateísmo é, em Holbach, antes a recusa de todo compromisso, seja ele tépido e simplório como aquele da Aufklärung, seja ele, a fortiori, especulativo, como quer a filosofia da religião de Hegel. No que diz respeito a esta última, capta-se um dos sentidos do ateísmo holbachiano, considerado como posição filosófica, mais do que como doutrina: impedir de buscar níveis de realização do verdadeiro, na

${ }^{26}$ Op.cit., p.114 e segs.

27 Phil.Hist., p.403, W., 12, p.531, grifo nosso.

${ }^{28}$ HEGEL, F.W., Introduction aux Leçons sur l'histoire de la philosophie, trad. Gibelin, Gallimard, 1954,

p.172, e Einleitung der Geschichte der Philosophie, Verlag von F. Meiner, 1971, p.192, grifo nosso.

29 Ver Introd., op.cit., p.322-324. 
representação e no conceito, e, por conseguinte, recusa-se a interpretar a história como uma Offenbarung, com a segurança de reencontrar, afinal, o que seria a possibilidade em si dessa história, tal como o diz Hegel: "Este acordo que existe para nós em si contém a possibilidade que na história real elas [a religião e a filosofia] passem também da consciência da oposição para uma verdadeira reconciliação". ${ }^{30}$ Inversamente, não é exagerado dizer que, do ponto de vista do hegelianismo, o ateísmo não teria sido senão uma doutrina aberrante, que se colocou fora da grande tarefa moderna da especulação.

Hegel não honrou o ateísmo com uma refutação, mesmo especulativa; muitos tentam sugerir algumas razões que expliquem por que o autor da Fenomenologia do Espírito não buscou compreender a significação do ateísmo holbachiano com a mesma simpatia que lhe fazia discernir, desde o período de lena, um autêntico impulso especulativo no Sistema da Natureza. ${ }^{31}$

No entanto, essa conclusão provisória tem algo de insatisfatório porque negligencia uma face importante da leitura hegeliana da filosofia francesa: aquela que conduz Hegel a afirmar que os franceses souberam realizar, nas condições específicas de sua cultura, e considerando seu atraso em relação à Alemanha reformada, a mensagem de Lutero na terra católica: afirmar os direitos infinitos para (e do) o pensamento livre. Como compreender que, no seio de uma época que afirma este princípio luterano, se elevava uma filosofia que se propunha a negar a existência de Deus e destruir a religião? Por isso, tratava-se então de captar o ateísmo em sua lógica imanente, e não mais apenas em sua relação com aquilo que ele quer negar.

Ora, precisamente, o ateísmo de Holbach oferece a possibilidade de uma tal aproximação. Nele, pode-se distinguir três níveis de crítica.

1) Apoiando-se naquilo que ele considera as conquistas da filosofia moderna (o racionalismo e o empirismo), Holbach opõe à teologia e à metafisica, quase sempre associadas, os princípios da evidência racional e natural. Em nome de sua potência explicativa, os pressupostos da teologia são desqualificados e afastados. Neste nível, a crítica é exterior e dogmática, já que ela se exerce a partir de um sistema de pensamento exterior ao de seu adversário e que ela admite como pressuposição absoluta.

2) A religião pode tornar-se, então, o objeto de um estudo profano e positivo, o que abre caminho para uma crítica redutora e desmistificadora. A religião, e

${ }^{30}$ Id., Ibid.., p.325, e Einleitung, op.cit., p.293, grifo nosso.

31 Em Différence entre les systèmes philosophiques de Fichte et de Schelling, trad. Méry (Vrin, 1952), p.157-158, e também Werke in zwanzig Bänden, Surkmap Verlag, 1971-1979, 2, p.119. Sobre este ponto, ver meu livro citado na nota 1. 
sobretudo o cristianismo, são submetidos às categorias de uma antropologia sensualista e materialista que encontra na história argumentos para recusar qualquer verdade ao fenômeno religioso.

3) A estas duas atitudes que permanecem exteriores ao seu objeto, Holbach acrescentou um terceiro modo, que se instala no interior mesmo do pensamento religioso, e parece admitir sua argumentação para lhe fazer confessar suas próprias contradições. Se, neste nível, o barão utiliza uma concepção de verdade empirista e revela uma severa lógica de identidade (tal como a jurisdição do critério da "utilidade"), é também porque a apologética, senão a própria teologia, as aceita e se expõe, consequentemente, a ser refutada em nome dos próprios princípios que a guiam. Tratar-se-ia de uma crítica imanente, inconscientemente "dialética", que confirmaria que ele seria criticado pelo que, no discurso religioso, era já em si ultrapassado ${ }^{32} \mathrm{e}$ por isso poderia prestar-se a um processo crítico de "autorrefutação". Apresentado assim, o ateísmo holbachiano torna-se capaz de ressoar com o texto hegeliano e dele tirar, talvez, um acréscimo de interesse e de significação.

Pretendemos ilustrar este ponto através de um exemplo. Ao revelar uma curiosa cumplicidade entre o sentimentalismo religioso e o ateísmo, Hegel permite compreender como Holbach pôde avançar as preposições de seu ateísmo a partir das falhas inerentes às doutrinas do "sentimento íntimo" do divino.

Essencialmente, a filosofia da religião de Hegel pode ser compreendida como uma dupla crítica da theologia rationalis dos modernos, isto é, enfim, o tratamento do conteúdo religioso segundo um "entendimento fariseu que opina sobre as coisas de um outro mundo com a mesma sabedoria que o faz a respeito das coisas deste mundo, e que pensa poder chamar esta sabedoria de doutrina da religião", ${ }^{33}$ e as variedades disto que ele chama de "saber imediato". Seu ponto de partida, a religião, é simplesmente pressuposto, empiricamente acolhido, e, assim, jamais é conceitualmente interrogado. É por isso que, como observa Hegel, recorre-se frequentemente a uma "categoria popular", já explorada por Cícero, a demonstração ex consensu gentium. ${ }^{34}$ Além disso, ao tomar a palavra "todos" ("todos os homens têm religião") em seu sentido banal e empiricamente extensivo, conduz-se a absurdidades (como admitir o boi Apis, o macaco ou a vaca dos indianos, como representações lícitas do divino), e a ideia de Deus que acompanha esta pseudo-determinação

\footnotetext{
32 Ver Hist.Phil., VI, p.1724.

33 Vorrede zu Hinrich's Religions philosophie (1822), W., p.11, p.52, citado e traduzido por G. Lebrun, op.cit., p.179.

${ }^{34}$ Ver Les Preuves de l'existence de Dieu, trad. Niel, Aubier, 1947, p.80, e W., 17, p.387.
} 
condena-se à maior das generalidades: "das Abstraktum von Gott überhaupt", ${ }^{35} \mathrm{em}$ conformidade com a vulgata da Aufklärung que repete que nada se pode conhecer do Absoluto, do verdadeiro em e para si. Resulta daí que ela não pode preencher-se com a amplidão concreta que lhe falta, senão na medida em que se diz que ela emana da crença, da consciência finita que se vê assim prometida à posição de medida do conteúdo da religião: "coloca-se todo o valor da religião no ponto de vista subjetivo". ${ }^{36}$ No entanto, o que escapa a esse subjetivismo formal que se fia tão surpreendentemente pela verificação empírica, é que ele abre o caminho para os críticos irreligiosos, ao ceticismo e ao ateísmo.

Assim, Holbach pôde escrever:

Se Deus tivesse falado, estranho seria que ele fosse falar de modo diverso a todos os seguidores dos diferentes cultos, que mutuamente todos se danassem, que mutuamente todos se acusassem, com razão, de superstição e de impiedade [...] o indiano não acredita em uma palavra do que Deus diz ao chinês, o maometano olha como fábulas o que Deus diz ao cristão; o judeu olha o cristão e o maometano como corruptores sacrílegos da lei santa [...] Quem tem ou não razão? Cada um exclama a si mesmo: sou eu! Cada um alega as mesmas provas. ${ }^{37}$

E conforme um de seus procedimentos mais constantes, Holbach retoma então contra seus adversários um de seus argumentos, aquele do consentimento universal:

Acredita-se calar a boca daqueles que negam a existência de um Deus, dizendo-lhe que todos os homens, em todas os séculos, em todos os países, reconheceram o império de uma divindade qualquer; que não haja povo sobre a Terra que não tenha tido a crença de um ser invisível e poderoso, do qual fez o objeto de seu culto e de sua veneração. ${ }^{38}$

E como melhor atestar essa universalidade do que enraizando a crença em Deus em um sentimento íntimo?

Desde que se recuse as provas que a teologia pretende dar da existência de Deus, opõe-se aos argumentos que a destroem um sentimento íntimo, uma persuasão profunda, um pecado invencível, inerente a todo homem, que expõe contra sua vontade a ideia de um ser todo poderoso que ele não pode expulsar totalmente de seu espírito, e que ele é forçado a reconhecer, apesar das razões mais fortes que possa alegar. ${ }^{39^{3}}$

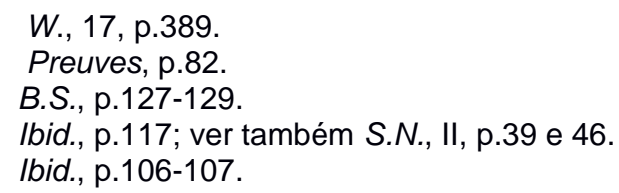


Mas a certeza posta nesse pretenso sentimento íntimo é insuficiente diante a diversidade de cultos e crenças que não conseguem fazer desaparecer no conceito de um Deus. A prova disso é que é necessário invocar sempre a Revelação. As disputas teológicas e seu cortejo de intolerância mostram que o recurso à violência é o símbolo da impossibilidade de alcançar uma real universalidade do sentimento do divino. Mas há algo ainda mais grave: ao apelar para um sentimento, o pensamento religioso iria dar a seu adversário um argumento de peso: como todo sentimento, ele é tributário da educação, e é inseparável de todo aparelho cultural e social que demonstra sua contingência, sua estrutura passional (o medo e a esperança) e, assim, sua incapacidade de ser realmente universalizado. ${ }^{40}$

Com esses dois temas (o consentimento universal e o sentimento íntimo), Holbach tomou para si dois lugares comuns do pensamento religioso que se aventuravam pelo terreno da naturalidade do sentimento religioso, e atacou antecipadamente os partidários do "saber imediato". Ora, mais tarde, Hegel revelará de maneira bastante clara a inconsequência que há em invocar um sentimento subjetivo para estabelecer a universalidade de uma verdade, já que todo apelo a um sentimento corre o risco de ver-se oposto a um outro sentimento também legítimo, mas cujo conteúdo pode ser diferente, e até mesmo contraditório. ${ }^{41}$ A crítica hegeliana visa, com efeito, o que o sentimentalismo necessariamente pressupõe, a saber, que é impossível conhecer Deus e que então "a finitude reina e torna-se o valor supremo", ${ }^{42}$ fazendo da causa de Deus um simples assunto particular. Ora, quando Holbach nega que Deus se encontra no sentimento, não se contenta em observar que o "pretensioso sentimento íntimo" é "o efeito de um hábito enraizado que [...] conduz o maior número de homens e, frequentemente, mesmo as pessoas mais esclarecidas, aos preconceitos da infância" ${ }^{43}$ e que, por conseguinte, aquele que é curado desses preconceitos, tem seu sentimento emudecido. Ele acrescenta que é em função das exigências da razão que o sentimento íntimo deve ser considerado sem força. Assim, "o que pode esse sentimento íntimo ou essa persuasão pouco fundada, contra a evidência que nos demonstra que aquilo que implica contradição não pode existir? ". 44 Evidência contra o sentimento, e não sentimento contra sentimento, esta é a posição de Holbach.

\footnotetext{
${ }^{40}$ Ver S.N., II, p.49 e segs., e B.S., p.142.

41 Ver La Raison dans l'histoire, trad. Papaioannou, U.G.E., 1965, p.63-64.

42 lbid., p.64.

43 B.S., p.107, ver também S.N., I, p.216-217 e II, p.42-43 e p.159-160.

44 Ibid..
} 
Se nós nos voltarmos para a lógica global da crítica de Holbach, poder-se-ia dizer que seu ateísmo se apresenta como um resultado, como o cumprimento consequente de um dos aspectos do sentimentalismo religioso. Se a religião, esvaziada de seu conteúdo substancial, repousa no sentimento subjetivo, então ela não faz grande coisa para fazer de Deus (de sua ideia, de sua intuição) um produto deste sentimento. É o que Hegel mostra de maneira notável: o encontro "objetivo" do sentimentalismo religioso e do ateísmo, pela via do materialismo:

Se, nessa desesperança do conhecer, renunciou-se a toda subjetividade substancial, necessária, e se o conhecimento de Deus é excluído desse domínio, para conhecer Deus não resta nenhuma fonte senão a subjetividade contingente, o sentimento; e a partir daí, não seria surpreendente que não se pudesse ainda atribuir a Deus, ao conteúdo que, dessa forma, depende de uma certa objetividade; afastou-se logicamente para o extremo esta opinião materialista, reduziu-se o pensamento ao simples elemento material, tomou-se Deus por um produto do sentimento; e o resultado foi o ateísmo, Deus tornando-se o produto da fraqueza, do temor, da esperança. ${ }^{45}$

Tendo demonstrado a inconsequência da consciência ingenuamente piedosa, Hegel faz do ateísmo uma consequência logicamente engendrada pelo sentimentalismo religioso. Nesse ponto seria equivocado censurar a intelecção materialista, ao dizer que Deus não é senão um produto dos sentimentos, já que é a própria intelecção materialista que iniciou o movimento dessa lógica, na sua recusa em conhecer Deus. Certamente, a fé não diz expressamente que Deus é um produto da subjetividade finita, mas ela não tem necessidade de dizê-lo, pois já deferiu que só é possível falar de Deus a partir da base do pensamento empírico e finito. É o sentimento e o saber imediato que justificam, em suma, o ateísmo quando, submetido a uma autocrítica interna, admitem sua inconsequência, e suas contradições revertemse em seu contrário.

Caso se aceite o esclarecimento hegeliano que chegamos a propor, seguido de um esquema de leitura da crítica interna, pode-se enunciar os seguintes resultados.

Ler Holbach, desse modo, é dar-lhe um presente envenenado: termina-se certamente justificando a necessidade conceitual de seu ateísmo e reforçando sua significação crítica do ponto de vista histórico e cultural; ao mesmo tempo, porém, o ateísmo fica limitado triplamente:

a) O ateísmo só é realçado sob a condição de ser interpretado como um momento da crítica geral da theologia rationalis e do saber imediato, momento necessariamente ultrapassado pela filosofia da religião hegeliana. De fato, os

${ }^{45}$ Phil.Relig., I, p.54; grifo nosso. 
pensamentos irreligiosos e ateus pós-hegelianos não recomendarão o barão, mas, significativamente, as Lições sobre a filosofia da religião. ${ }^{46}$

b) Seu conteúdo não tem autonomia, ele é condicionado por seu adversário, do qual é somente o resultado e com o qual divide o mesmo fundo epistemológico (o privilégio do ponto de vista do finito). Poder-se-ia perguntar-lhe a mesma coisa que se pergunta a Hegel, a respeito da "intelecção" das Luzes, uma vez assegurada sua vitória contra a fé: qual é seu conteúdo próprio, autônomo? ${ }^{47}$ O que confirmaria indiretamente um dos sucessores de Holbach, S. Maréchal, ao escrever:

O verdadeiro ateu não é tanto aquele que diz: "Não, eu não quero um Deus", mas aquele que diz: "Eu posso ser sensato sem Deus" [...]. O ateísmo sendo a coisa do mundo mais natural e a mais simples, [sem] disputar a favor ou contra a existência divina, o ateu vai seguir corretamente seu caminho e fazer por si o que os outros fazem por seu Deus. ${ }^{48}$

c) Enfim, recolocado no interior de uma época que, no ser-aí social e cultural dos homens, enxerga o triunfo da mensagem da Reforma, o ateísmo que aparece como seu agente involuntário é interpretado, finalmente, como tendo contribuído para liberar o pensamento das limitações do entendimento abstrato e da arbitrariedade do sentimento; com isso, porém, perde sua virulência.

Pode-se perguntar se o ateísmo merece uma outra atenção além da "histórica" e, neste caso, interrogar-se sobre o relativo desaparecimento desse tema hoje. Em contrapartida, deve o ateísmo ser reativado, caso se estime que o pensamento livre está sempre ameaçado pelos devotos de toda espécie ou pelas seduções do mais tolo irracionalismo? Não há nenhuma dúvida de que, nessa hipótese, seria útil tomar a medida de nossa tradição ateia e reler as obras de Holbach restituindo-Ihe toda sua violência libertadora.

\section{Referências bibliográficas e abreviações}

D’HOLBACH. Système de la nature, édition de 1821, réimpr. Olms 1966 (S.N.). . Le Bon Sens, Les Éditions rationalistes, 1971 (B.S.).

\footnotetext{
${ }^{46}$ Ver J. D'Hondt, "La 'Philosophie de la Religion' de Hegel”, in Hegel et la Religion, publicada sob a direção de G. Planty-Bonjour (PUF, 1982), p.35.

${ }^{47}$ Ver Phénoménologie... op.cit., t. II, p.109.

${ }^{48} \mathrm{~S}$. Maréchal, Dictionnaire des athées anciens et modernes (Bruxelles, 1833), p.VI e XXXVIII.
} 
HEGEL, F.W. : Leçons sur l'histoire de la philosophie, trad. Garniron, Vrin, 1954 (Hist.Phil.).

. Introduction aux Leçons sur l'histoire de la philosophie, trad. Gibelin, Gallimard, 1954 (Introd.).

. Einleitung der Geschichte der Philosophie, Verlag F. Meiner, 1971 (Einleitung).

. Leçons sur la philosophie de l'histoire, trad. Gibelin, Vrin, 1946 (Phil.Hist.).

. La Raison dans l'histoire, trad. Papaioannou, U.G.E., 1965 (Raison).

Leçons sur la philosophie de la religion, trad. Gibelin, Vrin, 1971 (Phil.Relig.).

Les Preuves de l'existence de Dieu, trad. Niel, Aubier, 1947 (Preuves).

Werke in zwanzig Bänden, Suhrkamp Verlag, 1971-1979 (W.) 